\title{
Recognising Adulthood? Young Adults' Accomplishment of their Age Identities
}

\author{
By Andrew King
}

Published in Sociology, 47(1): 109-125

\begin{abstract}
This paper seeks to extend work in the growing sociology of adulthood. It considers the debate that young people in the UK and other advanced industrial societies now face challenges to their adulthood; in particular, that they experience problems of social recognition. Using membership categorization analysis (MCA) the paper then illustrates how members of a sample of twenty-three young people who had taken a Gap Year, a break in their educational careers taken between leaving school/college and university, use talk about changes in their relationships with their parents during this period of their lives to accomplish an adult identity in their current context. The paper considers the ramifications of these findings and the consequences for studying adulthood more generally.
\end{abstract}

\section{Keywords}

Adulthood, Gap Year, membership categorization analysis (MCA), recognition

\section{Introduction}

Adulthood forms the "unarticulated background” of much sociological investigation (Blatterer, 2007a: 57), yet a sociology of adulthood has only recently begun to emerge (Blatterer, 2007a; Pilcher et al., 2003; Burnett, 2010). Hence, the need to question, to decentre and critically engage with this categorisation remains imperative (Burnett, 2010).

Research has suggested adulthood has changed, reflecting broader social transformations (Arnett, 2004; 2006; Côte, 2000; 2002; Côte and Bynner, 2008; EGRIS, 2001). Sociological studies of youth, for instance, have demonstrated that young people are struggling to become adults, certainly when compared to previous generations (for examples see Arnett, 2004; Côte, 2000; Maguire et al., 2001; Plug and du Bois-Raymond, 2006). Mirroring this, there has been a growing popular debate in the UK in recent years concerning the structural challenges faced by young adults (Howker and Malik, 2010; Rawnsley, 2006; Beckett, 2010; Willetts, 2010). The suggestion postulated by such authors is that a new form of generational divide is becoming apparent; the young are in debt to their parents, both financially and in terms of social recognition. However, as Blatterer (2007a; 2010a) has observed, such 
contentions are often based upon a 'standard model' of adulthood, a historical and ideological construct, which nonetheless retains a normative force despite the real world, lived realities of young people themselves. There is, Blatterer contends, a recognition deficit at the heart of our understanding of adulthood, which must be negotiated by young people.

This paper seeks to add new critical insights to this debate by focusing on the discursive practices used by a group of young people to accomplish their age identities in a specific context: an interview about their Gap Year, a break in their educational careers taken between leaving school and beginning study at university. The Gap Year is an interesting phenomenon for a number of reasons. Firstly, it is a ubiquitous, if under-researched, feature of the lives of a significant proportion of UK undergraduates, with studies indicating that anywhere from a tenth to a half could have taken a pre-university Gap Year (King, 2011; Heath, 2007). Secondly, a preuniversity Gap Year represents an interruption, a 'critical moment' (Thomson et al., 2002), in institutional transitions and consequently in these young people's transitions to adulthood. Thirdly, media and Gap Year provider organisations frequently represent it as a forum for young people to develop themselves, making them more mature, independent and confident, and potentially more employable, although the diversity of Gap Year experiences means that a hierarchy exists with overseas volunteering regarded as the 'gold standard' (Heath, 2007).

This paper is not, however, an evaluation of the Gap Year per se, or why young people might decide to take a Gap Year (for that see Heath, 2007; Simpson, 2005). Nor does the paper seek to compare the adulthoods of gap year takers to those who have not taken a Gap Year. Instead, by drawing on ethnomethodology and conversation analysis the paper examines the interactional identity work that is undertaken when accounts of such experiences are given. Specifically, it looks at how a group of young people use accounts about changes in their relationships with their parents, both during and after their Gap Year, as a discursive resource that enables them to gain recognition for their adult identities in the here and now. Parental recognition has long been viewed as central to how young people understand their adulthood (Baker, 1984; Henderson et al., 2007; Holdsworth and Morgan, 2005), although it is correlated to other factors, such as social class, gender, ethnicity, 
sexuality, and disability amongst others (Monteith, 2003; Wells et al., 2003; Wyn, 2004; Henderson et al., 2007). In this paper, however, attention is directed to the micro-practices of identity work that are undertaken when such accounts are given, relating them to wider discursive and social understandings associated with age.

The paper begins with a brief discussion of the constitution of adulthood, before considering the notion that achieving adulthood is a matter of recognition. Subsequently, the methodology used to gather and analyse the data reported on in this paper will be outlined. Empirical examples are then discussed in detail to illustrate how recognition of adulthood is accomplished at an interactional and intersubjective level. The paper concludes by considering the ramifications of these findings for the sociological analysis of adulthood more generally.

\section{Adulthood and its recognition}

Many of our understandings of what it means to become an adult emerged during the modern era, the product of economic, social and cultural changes in how children, youths and the elderly were conceptualised and institutionalised (Ben-Amos, 1995; Shanahan, 2000; Jenks, 1996; Phillipson, 1982). Becoming an adult has been associated with a variety of rights, entitlements, obligations and competencies; the outcome of a developmental maturation process (Hockey and James, 1993; Jenks, 1996; Hutchby and Moran-Ellis, 1998). Additionally, it has been associated with the attainment of certain structural markers, including, but not limited to: gaining fulltime employment; leaving the parental home; committing to a monogamous relationship; and parenthood (Furlong and Cartmel, 2007; Jones, 1995; Wallace, 1987).

This 'standard model' reached its zenith in the mid decades of the $20^{\text {th }}$ Century, during a period of sustained economic stability and social conservatism (Blatterer, 2007a). Since the 1970s, economic, social and cultural factors have challenged and undermined its ontological basis, resulting in greater uncertainty and flexibility about what it means to be an adult for young people in their late teens and twenties. Concurrently, representations of youth have become detached from chronological age and repackaged for all age groups, provided they are divested of its unruly elements. To be youthful, especially when one is beyond one's twenties, is 
inscribed with positive connotations, such as flexibility and vitality. Hence, the distinctions between youth and adulthood, as recognisable stages of the life course, have become blurred, creating further problems of recognition for young people themselves (Blatterer, 2010a).

For some writers this means that young people now defer full adulthood (Côte, 2000; Pais, 2003; Plug and du Bois-Raymond, 2006; Maguire et al., 2001), whilst for others they are 'emerging adults', pioneers of a new stage of the life course between youth and full-adulthood (Arnett, 2000; 2004; 2007). Young people now have to construct their own life course trajectories in individualised ways, often drawing on psychosocial attributes such as maturity and independence in an ad hoc manner. For some young people this represents an opportunity; whilst for others, it is burden that it thrust upon them. Indeed, studies suggest that factors such as social class, gender and ethnicity still shape the life chances of young people, the rapidity at which they become adults and the form of adulthood that they emerge into (Henderson et al., 2007; MacDonald and Marsh, 2005; Ball et al., 2000; Jones, 2002; Jones and Wallace, 1990). However, as Blatterer (2010a) has observed, this is not only problematic for the young per se, but tells us something about social recognition (Blatterer, 2007b; 2010a); or, as others have asserted, young people's adult identities are highly contestable under certain circumstances (Horowitz and Bromnick, 2007).

Blatterer's work (2007b; 2007a; 2010a; 2010b) draws extensively on Axel Honneth's theory of social recognition (Honneth, 1996) arguing that the standard model of adulthood has now lost its authority. Despite this it remains a pervasive force in young people's attempts to gain recognition as adults and also in social scientific measures of adulthood. In essence, Blatterer is pointing to a disjunction in 'real world' understandings of adulthood, as produced by young people themselves, and those who confer recognition on their identities: adults of the baby boomer generation, journalists and social scientists. He asserts (2007b: 786) that:

"far from living a prolonged adolescence, new adults are in effect particularly well integrated in a world that is radically different from the past. However, the relations of adult recognition underpinning these changes are riven with contradictions. Practices may be at once structurally rewarded and discursively misrecognized because the normative ideals of another time remain most 
readily associated with what it means to be an adult, a 'full person'... As a consequence, the new modalities of adulthood are marked by a recognition deficit.”

Thus, Blatterer argues that exploring processes of recognition in specific contexts remains an important goal for sociologists. This is especially significant if we are to avoid reproducing normative understandings that have little basis in social reality, which can result in the production of outmoded social and political policies that disempower the young.

Blatterer's argument is persuasive and in addressing the politics of recognition he clearly challenges sociologists to reconsider adulthood. However, as he himself acknowledges (Blatterer, 2007a), his work is predominantly theoretical and his empirical examination draws on a sample of young people aged between 25 and 35 years of age. Although by no means irrelevant, since he demonstrates clear support for his hypothesis, it remains necessary to examine how such forms of recognition are managed in specific contexts, particularly by a younger age group who are perhaps more vulnerable to having their adulthood challenged.

Adopting a somewhat different theoretical perspective, although viewing intersubjective recognition as central, Horowitz and Bromnick (2007) surveyed a sample of 156 young people aged between 16-17 years of age to illustrate that their adulthood is a highly 'contestable' identification. They must distinguish themselves from children, whilst simultaneously ensuring that their identity is recognised as adult by people who they consider are members of this category: for example, parents, teachers, employers. Consequently, a certain amount of identity work must take place, or as the authors assert: "this leads us to propose that, not only is the category “adulthood” an essentially contestable concept but also any individual's membership of the category "adult" is only contestable during a certain period of the life course" (ibid: 212). They do not try to define this period of the life course chronologically; rather, they argue that it can be analysed by exploring young people's rhetoric about age.

Horowitz and Bromnick’s work, like Blatterer’s, shifts the debate significantly towards viewing adulthood as a process of intersubjective recognition, rather than a 
predetermined social fact. Moreover, they are able to demonstrate that problems of recognition can be experienced by a younger age group. However, surprisingly, their use of a quantitative survey, which required young people to identify adult traits and behaviours, misses something that is central to their argument: the significance of performing adult identities in specific contexts, primarily through the use of talk. Furthermore, by sampling young people, all of who were secondary school pupils, their findings were based on a cohort who may not have reached a point in their lives where they had begun to categorise themselves as adults or have this identity recognised by others. As such, these young people were inferring something about adulthood, rather than demonstrating how and why their own adulthood was contestable.

To summarise, despite limitations, the aforementioned studies clearly illustrate that adulthood is a problematic social category, something that creates tensions at both macro and micro levels, especially for young people. They challenge us to examine this problem in more detail, whilst avoiding the reification of our own understandings. However, this paper will demonstrate that our knowledge could be extended by focusing on how recognition is manifested in specific settings and how young people's age identities are accomplished in these settings through the use of talk.

\section{Accomplishing Age Identities}

The notion that identities are accomplished is central to a number of perspectives within sociology including the work of Goffman (1971). However, whilst Goffman presumes the existence of an a priori self that is then manipulated in interaction, ethnomethodology (Garfinkel, 2005) and conversation analysis (Sacks, 1995) focus on identities as situated accomplishments, demonstrating a person's understanding of who they are in that situation, principally by their use of talk, or 'talk-in-interaction' (Antaki and Widdicombe, 1998). Thus, in such circumstances, normative understandings of age categories act as a toolkit for individuals to construct their 'age' identity through interactional work; it is not simply a biological fact (Laz, 1998). This is evident in several existing studies of different age identities, which draw upon ethnomethodology and conversation analysis. 
Nikander (2002) demonstrated how a sample of women interviewed about their approaching $50^{\text {th }}$ birthday used categories such as 'old', 'young' and 'little girl' to position themselves as neither young nor old in response to certain questions. Thus, how they performed their age identity as 'middle-aged' reflected their interpretation of social expectations and what the interviewer required of them.

Focusing on young people, Baker (1984) interviewed teenagers to show how they accomplished this identity as distinct from both childhood and adulthood by drawing upon readily available categories, such as those associated with play, with relationships with parents, with roles, suggested by the interviewer's questions and their own examples. Using these creatively, they carved out what constituted a 'teenager' for them. Meanwhile, Widdicombe and Wooffitt (1995) showed how young people's membership of youth subcultures was a highly pragmatic and situated identification. Being a member of a youth subculture, they concluded, was dependent on who was asking about membership and what that young person understood the situation required. Cumulatively, these studies demonstrate that any age identity is accomplished at a particular point in time, to display a person's understanding of that identity using discursive resources that are made available within the situation, but which also draw on wider social structures and meanings.

\section{Age as Category and Adulthood as Membership}

Central to the studies outlined above are membership categories, devices and predicates (Sacks, 1995). Categories can be people, places and objects, whilst predicates are actions or characteristics that are bound to categories. Categories are arranged into devices (MCDs) or collections, although a single category can belong to many devices: for example, the categories 'mum' and 'dad' can belong to the device 'parents', and the device 'family'. Therefore, the meaning of each category is situational; it is how people use categories, devices and predicates in a specific instance that is significant. Substituting one category for another, or similarly one predicate for another, enables people to reflect and reconstruct both normative and moral orders (Jayyusi, 1984). This mechanism represents ‘culture-in-action’ (Baker, 2000): tacit, culturally specific forms of knowledge, carried by discourse, which are reproduced and transformed in use. The analysis of categories, devices and predicates is referred to as Membership Categorisation Analysis (MCA) (Lepper, 2000; Sacks, 
1995) and this is the analytic approach used in the methodology of the study reported upon in this paper.

\section{Methodology and analytic approach}

Twenty-three young people aged between 19 and 26 years of age were recruited by convenience and snowball sampling as part of a study examining young people's experiences of taking a Gap Year (King, 2009; 2011). Two thirds of the participants were female; only two participants, both female, identified themselves as having a minority ethnic identity. Whilst not a representative sample, this sample did have similarities with those of previous studies, which suggest that Gap Year takers are more likely to be female, white, middle-class and from Southern England (Jones, 2004). Conversely, a third of the sample identified themselves as being either working-class, or having a working-class background. Half of the sample spent their Gap Year working in the UK and then travelling overseas; half worked exclusively in the UK, although there was considerable variation in the forms of employment they had undertaken. All members of the sample, except one, were university students. This is important because these young people are in a liminal position in their lives, neither fully independent adults, nor dependent children (Arnett, 1994). As such, their age identities are particularly contestable and open to misrecognition and they must work to accomplish their adulthood using a range of resources made available within the context in which they are framed, in this case an interview about their Gap Year set within the context of Higher Education.

The majority of interviews took place in university contexts, such as seminar rooms and offices. Unstructured interviews were conducted by a recognisably middleaged academic and lasted between sixty and ninety minutes. Participants were invited to tell the interviewer the story of their Gap Year, although a topic guide was employed to prompt for the following details if necessary: family and educational background; reasons for gap year; unexpected events; decisions about university; university experiences; and thoughts about the future.

The interviews were conceptualised as active discursive spaces for the construction of accounts, representing the interviewer and interviewee's understandings of the situation in which they were located, rather than as forums to 
uncover objective 'truths' (Holstein and Gubrium, 1995; Baker, 2002). They were analysed using a three stage MCA administered via NVivo qualitative data analysis software (see King, 2010). This involved: identifying key membership categories, devices and predicates (CDPs) within the sample; mapping the sequence of these CDPs within each account and across the sample; and identifying how certain CDPs were treated as anomalies or disruptions by the co-participants in the talk that required some form of explanation or 'repair' work. Other discursive features related to identity work, such as special forms of knowledge, 'collection K' (Sacks, 1995), and ‘contrast statements’ (Smith 1978) were also identified. In accordance with MCA principles, other social identities were viewed as relevant, but only if made relevant by members in the talk-in-interaction ${ }^{\mathrm{i}}$. However, to contextualise the analysis, some biographical details for each participant have been added and some conversation analysis conventions are used in the extracts (for an overview see Have, 1999).

\section{Accomplishing Age Identities in Gap Year talk}

The MCA demonstrated that this sample of young people made reference to a number of key people in their accounts, including friends, employers and teachers. However, the use of the category 'parents', which in most instances was not prompted, was especially notable. It became apparent that talk about changes in their relationship with their parents, both during and after their Gap Year was not arbitrary; rather, it enabled these participants to present themselves as 'candidate' (Potter, 1996) adults; something that could then be recognised or not by the interviewer as part of the interaction.

The first case that I will discuss comes from Claire's account. Claire was twenty-one years old and in the final year of her degree when interviewed. She had worked in the public sector during her Gap Year, whilst living at home with her parents. In the following extract she is discussing how her parents reacted to her decision to take a Gap Year when she had failed to obtain the necessary 'A' level grades she required to gain entry to her desired university.

289: Claire: and so they [parents] were like 'ok fine (.) what are you going to do' 290: $\quad$ so I said (.) 'well I'm going to (.) y'know I think I'll redo my 'A' level and I think I'll do this (.) and I'll get a job and I'll make it work'

291: $\quad$ and erm I think perhaps to start with they were a bit sceptical 
292: but (0.2) I think that (.) a few months into it my mum said to me 'oh erm (0.1) I think this was one of the best decisions you could've made (.) 'cos I don't think you were ready to go'

293: 'and I'd never had said that to you (.) but you weren't ready'

294: Int: $\quad$ yeah (.) what do you think she meant by that

295: Claire: I think erm (0.1) I dunno (0.2) I think perhaps she meant that (.) not necessarily intellectually (.) but mentally perhaps I wasn’t ready to let go of being at home

296: $\quad$ so I think (.) by the time I actually went (.) I was much more ready to cut my ties off with er (.) being at home

297: Int: hmmn

298: Claire and sort of (.) start to go off a bit

299: Int: did you feel that you we:re changing during that year

300: Claire: I think I grew up quite a lot

301: Int: yes

Claire's account here begins with categories associated with the MCDs 'education' and 'employment' and she initially indicates that her parents were concerned about how should would spend her Gap Year. This is perhaps unsurprising and accords with previous research, which indicates that adults govern the time of young people and that young people stress the importance of using their time wisely to such significant others (Scanlon et al., 2007; Qvortrup, 1994). What is noteworthy here, however, is the section of talk starting at line 292 where Claire shifts from using these MCDs, introducing something that was observed by her mother at the end of her Gap Year. The interviewer hears this change of register as significant, since it precipitates a call for clarification (line 294). In her response, Claire dismisses an academic explanation, which could be inferred by her previous discussion of her failed 'A' level. Instead, she invokes the predicate 'mentally', linking this directly to her family home. Thus, Claire's categorisation work can be heard as a rhetorical move to explain to the interviewer that her decision not to leave home during her Gap Year was not simply a practical matter; it was ontological, related to her self. It is, however, in response to a further question that Claire suggests that this ontological change was related to her age identity (line 299); a statement that implicitly puts her in the category 'candidate adult' since it has already been recognised by her mother. This identity position is then recognised by the interviewer (line 301).

Claire's adult identity emerges implicitly in her account. Other participants, however, were more forthright in explaining how changes in their relationship with 
their parents had transformed their age identity. One example, outlined below, is taken from Scott's account. He spent his Gap Year living at home with his parents, whilst working in the retail sector:

931: Scott: $\quad y^{\prime}$ know (.) and (.) I actually found that a massive bond occurred between me and my parents

932: Int: $\quad$ oh $\uparrow$ [right]

933: Scott: [as] well

934: Int: yeah

935: Scott: $\quad y^{\prime}$ know (.) like a huge amount of bonding happened between (.) especially between me and my dad

936: $\quad$ I mean it's not that my parents (0.1) like we didn’t get on

937: Int: yeah

938: Scott: but (.) the relationship changed

939: Int: yeah

940: Scott: and suddenly [they]

941: Int: [what] ways do you think?

942: Scott: yeah (.) they were giving me respect

943: Int: right

944: Scott: $\quad$ erm (.) y'know (.) I'd identified what I wanted to do

945: $\quad$ and they were sort of supporting me through it

946: $\quad$ but $y^{\prime}$ know I was (0.1) I had the attitude that I wanted to pay my own way

947: Int: $\quad$ yeah

[...]

956: Scott: $\quad$ y'know and (0.1) it's like not necessarily that we didn't get on before

957: $\quad$ but as a kid you always think of your parents as like (.) y'know (0.1) as parents

958: Int: $\quad$ yeah

959: Scott: whereas (.) throughout the course of that year (.) they changed from being parents $(0.1)$ to being more like friends

960: Int: yeah

961: Scott: $\quad$ y'know (.) and like (.) you sort of (0.1) it sounds really bad

962: $\quad$ but you sort of learnt (.) I really learnt to love my parents in that year

963: Int: yeah

964: Scott: just because I matured so much

965: Int: yeah

This extract contains a sequence of assertion/recognition turns on the part of Scott and the interviewer, which follow Scott's assertion that a 'massive bond occurred' (line 931). This is heard as noteworthy because the interviewer both exclaims and interjects, 'oh right' (line 932). Scott indicates that there was a change in the affective nature of his relationship with his parents during his Gap Year, which reflects previous research studies regarding a change in the affective nature of the 
parent-adult child relationship in young adulthood, becoming more like a friendship (Proulx and Helms, 2008). It is interesting to note here how this account of changing relationships is managed through Scott's use of categories and predicates and consequently what effect this has on his age identity.

Scott invokes two categories from the MCD 'family': 'kid' and 'parents' (line 957). This is a standard relational pair (SRP) (Sacks, 1995) that is associated with certain rights and obligations: for example, it is commonsensical that parents have certain responsibilities towards their 'kids' and 'kids' will have certain obligations towards their parents. Moreover, Scott's use of the 'family' MCD is significant because members of this collection can also belong to the collection 'stage of life' (Sacks, 1995; Silverman, 1998). Hence, 'kid' equates to 'child' and 'parent' to 'adult'. Since he no longer identifies himself as a 'kid', Scott not only shifts the form of the relationship in terms of affect, but he also reclassifies himself as a co-member of his parent's category; although Scott continues to be a 'son' he is no longer a child. Indeed, his use of the predicate 'matured' (line 964) serves to emphasise and explain this difference. In effect, Scott's account can be recognised (or misrecognised) as a positioning of his age identity in terms of adulthood.

Scott was not the only participant to use the category 'kid' in this way. In the following extract, Sarah is discussing conversations she had with her parents before and after her Gap Year travels. In so doing, she shifts her identity from 'kid' to 'adult':

1263:Sarah normally (.) you talk to your parents (.) but you don’t have anything to say

1264: Int: hmmn

1265: Sarah: there's nothing really to talk about (0.1)

1266: $\quad$ what do you talk about <'how was your day at school'>

1267: $\quad$ (.) 'the same as every day'

1268: Int: ye:[ah ]

1269: Sarah: ['the] same as every single day for the last ten years' (laughs)

1270: $\quad$ and suddenly having stuff to talk about (.) that's not just kiddie stuff

1271: Int: $\quad \mathrm{hm}[\mathrm{mn}]$

1272: Sarah: [stu]ff that they'd be interested in

1273: Int: yeah

1274: Sarah: and (.) stuff that they'd like to have done

1275: and like to do 
1276: $\quad$ so ringing her when I was away (0.1) I could talk to her more on a level than as a (.) kid

1277: $\quad$ and erm (0.2) when I came back that sort of carried on

1278: Int: hmmn

1279: Sarah: so it made sort of things (0.1) better just (.) made the relationship more equal

1280: Int: yeah

1281: Sarah: rather than parent-child sort of thing

1282: Int: yeah

There are several significant features to the talk-in-interaction here. Firstly, Sarah uses the category 'kid' to infantilise her pre-Gap Year conversations with her parents, contrasting these to ones that occurred afterwards. She thereby makes these developmentally appropriate; that is, to appear normal and 'natural' for her life course position (Baker, 1984). Secondly, her claim that her relationship with her mother had become more equal (line 1279), is recognised by the interviewer (line 1280). This is then reinforced by Sarah who explicitly invokes the SRP (Sacks, 1995) 'parent-child' (line 1281). Again this is recognised by the interviewer (line 1282).

The accounts given by Scott and Sarah illustrate support for the contention that the transition to adulthood is marked by a change in power dynamics between parents and their adult children (Buhl, 2009). More importantly, they demonstrate how recognition for one's own adult status can be asserted through talk about its recognition by significant categories of others: parents (Blatterer, 2007a). It is arguable, however, that by making such explicit statements these young people open themselves to a challenge. When they claim that their relationship with their parents had became more equal, the interviewer could have disagreed. Why, we might speculate, did this not occur in these interactions? Explaining this from an ethnomethodological/conversation analytic perspective means locating an explanation in the content of the talk, rather than a priori or external factors e.g. interviewer effects, power.

The MCD 'parents' represents a set of categories that have a moral value (Jayyusi, 1984) and which are normatively associated with special knowledge, what Sacks (1995) referred to as 'collection K'. Parents are said to know their children better than anyone else and much public and political rhetoric draws on and reinforces this presumption. The interviewer could have questioned the individual's adulthood, 
by questioning whether it had really been recognised by parents; this could, however, be taken as a direct challenge to their parents' authority and understandings of their children. In ethnomethodological terms, it would have represented a 'breach' in the interview, a questioning of the 'truthfulness' of the account that would have required some form of repair. This did not occur directly in any of the interviews; however, some participants used such breaches themselves in their accounts, with particular interactional consequences for their accomplishment of their age identities.

In the following extract, Abby gives an account of a problem she experienced returning to her parental home after her Gap Year travels. In so doing, she points to an asymmetry related to her age:

851: Int: $\quad$ so did you feel that you:d $>$ kind of $<$ grown up a lot

852: Abby: yeah

853: $\quad$ I mean (.) my mum did say 'oh my little girl left and now like (.) she's come back a lady (.) or woman sort of thing'

854: Int: yeah

855: Abby: I think my parents did say they saw a massive difference in me

856: $\quad$ but (.) they also said it was a good thing

857: Int: [yeah]

858: Abby: [the] change they saw in me

859: $\quad$ I did feel that I'd kind of (.) had this independence

860: $\quad$ and I was on my own

861: and then (0.1) sort of I was coming back into this family unit where there was my mum and my dad and er (0.1)

862: I'd been able to go out and do what I wanted for se:ven months

863: $\quad$ and (.) I mean (0.1) my parents had never sort of really stopped me doing anything

864: $\quad$ but (0.2) it was still kind of like when I was going out

865: 'well where are you going?'

866: $\quad$ and like 'just checking that you're ok' sort of thing

867: $\quad$ and it was like (0.1) 'you didn't really have this choice when I was the other side of the world'

868: $\quad$ it was (.) that was a kind of learning experience for both of us

869: 'cos my parents really had to realise that I'd done this kind of thing on my own

870: and been independent to a certain extent

871: $\quad$ and I kind of had to bite my lip thinking 'yeah well (.) y'know I'm still their daughter and this is still their house'

872: Int: yeah

873: Abby: and that kind of thing so

874: Int: yeah

875: Abby: it was a bit difficult at first 
Responding to a question about her age identity, Abby positions herself as adult by asserting that it was her mother who recognised this (line 853). Like the previous examples, this is subsequently recognised by the interviewer (line 854). However, Abby then employs a 'contrast structure' (Smith, 1978), pointing to a problem with this identification. This begins at line 861 and continues until line 867. Abby suggests that both parties had to consider the experiential effects of her changed identity, but particularly herself: 'I kind of had to bite my lip' (line 871) and 'it was a bit difficult at first' (line 875). Hence, although Abby is asserting her own adultness, as recognised by her parents, particularly her mother, she is also illustrating that accomplishing this identity in certain situations could be problematic. Although she illustrates this with reference to her family home, it is arguable that the same could apply to her current situation: university. Indeed, the significance of emphasising adulthood in a university context and contrasting it to the parental home was emphasised more forcefully by David, who, unlike Abby, remained in his family home during his Gap Year.

330: Int: erm (.) how did your parents’ react?

331: did it feel different?

332: David: it was very different

333: Int: yeah

334: David: 'cos in the Gap Year I was getting up early

335: Int: hmmn

336: David: I was working from say I don't know half eight till (.) getting back at half five six o'clock

337: $\quad$ and in the evening just chilling out

338: Int: yeah

339: David: and my mum sort of respected that when I was (.) away from home I was working

340: $\quad$ and when I was at home I could sort of do some chores around the house

$[\ldots]$

351: David: when I was at home and I was doing my Gap Year thing I felt I was very much the baby son

352: Int: right

353: David: at mummy and daddy's house

354: $\quad$ that sort of thing

355: Int: yeah

356: David: then when I was at uni I was like proper grown up (0.1) $\uparrow y^{\prime} k n o w$ 357: Int: yes 
As we saw with Scott's account, David initially positions his relationship with his parents, particularly his mother, as 'respectful' during his Gap Year. This is achieved by his utilisation of MCDs related to 'employment' (lines 336) both paid (339) and domestic (line 340). We can hear this as an active assertion of his independence and recognition by his mother as such. However, by pointing to a 'breach' in this identification, David infantilises himself during this period: a 'baby son’ who was ‘at mummy and daddy’s house' (lines 351 and 353). Again, a 'contrast structure' (Smith 1978) is employed, whereby David contrasts this to his identity in his current location, university, where he is 'proper grown up' (line 357). Moreover, David invites the interviewer to recognise this with the assertion, ' $y$ 'know' (line 357). In conversation analytic terms, this orients a preferred agreement response: 'yes', which is the response that David receives (line 357). Again, like Abby, by pointing to a potential challenge to his adult identity in his relationship with his parents, and by using features of talk-in-interaction, David accomplishes an adult identity in the here and now.

Overall, the preceding analysis has demonstrated that it is possible to view these young people's accounts of changing relationships with parents during their Gap Year as a discursive resource, which enables them to accomplish an age identity in other contexts. In the following section of this paper, the wider sociological ramifications of these findings are considered.

\section{Discussion and Conclusion}

The purpose of conducting a MCA on these young people's accounts was to examine the identity work that they were undertaking in the context of an interview about their Gap Year. The analysis has shown that using the category 'parents' in these accounts was not indiscriminate; it enabled these young people to present themselves as adults. The paper has not sought to assess the validity of such identifications; for instance, we have no way of knowing whether their parents regarded their experiences as making them more adult. Instead, the paper has sought to extend the work of those who assert that achieving adulthood is about recognition (Blatterer, 2005; 2007a; 2010b; Horowitz and Bromnick, 2007) and consequently that age identities are interactional, intersubjective accomplishments. 
Before considering the ramifications of this for sociology more broadly, some limitations with this study should be considered. Firstly, the study on which this paper is based was concerned with the identity work undertaken by young people who had taken a Gap Year. It is therefore not possible to compare their identity work directly to young people who have not taken a Gap Year. There may, for instance, be different discursive practices at play; different categories, devices and predicates are likely to be utilised and future research could examine these in instances of talk-in-interaction. Secondly, the young people's parents were not interviewed because the focus was on the young people themselves. Again, future research could explore the discursive practices used by parents of adult children; or joint interviews could be conducted to examine the intersubjective accomplishment of adult identities in situ.

Despite these apparent limitations, this paper has shown how young people use the ‘inference-rich’ (Sacks 1995) nature of categories as a rhetorical device for accomplishing an adult identity in a specific context, higher education, where, as others have noted, this is particularly open to challenge (Holmstrom et al., 2002; Scanlon et al., 2007; Brooks, 2003). Undertaking identity work via the use of a valorised category such as 'parents' in this context therefore adds authority and validity to their claims to adulthood: for example, to contest such an assertion is more risky than questioning a peer's observation; it has a moral and normative force, although it is important to remember that these accounts are crafted for a specific purpose and that at other times, such as in conversations with peers, the category 'parents' may not be used. Yet the paper has also demonstrated that recognition in this specific context was relatively unproblematic. Having established this we might ask why is such a mundane practice relevant?

It is here that these micro practices must be linked to wider debates. The paper began by suggesting that becoming an adult is often regarded as challenging in contemporary, advanced industrial societies, such as the UK. As noted previously, this has been represented in popular discourse as evidence of a growing generational divide. Yet the accomplishment of adult identities by the young people discussed in this paper should alert us that as sociologists we do not overemphasise such popular hyperbole by implying that becoming an adult is now something so problematic that it is inherently disordered. Whilst young people face many challenges, I would concur 
with Blatterer (2007a: 118) when he asserts: "the new adults of today may be without a center that holds. But, they are no more and no less than matchless actors in times of uncertainty." Viewing adulthood as an accomplished identity, something that is recognised or not in specific circumstances, by different groups of social actors, remains a goal of future research. This could take the form of examining its accomplishment in more naturalistic settings, such as job interviews, where the stakes of performing certain types of adult identities are much higher. Similarly, exploring how age identities intersect with other categories of identity such as gender, ethnicity or class, amongst others (Housely and Fitzgerald 2002), should be addressed. This would mean exploring how these identities emerge in the talk-in-inaction, rather than determine it in advance, in much the same way that age has been investigated in this paper. Examining this complex yet mundane identity work remains important if we are to continue to critically address issues of recognition, whilst seeking to avoid the generalisations and oversights that resound in popular discourse.

\section{Acknowledgements}

The author would like to thank Geoff Cooper and Jo Moran-Ellis, both University of Surrey, for all of their support and advice over many years. Additional thanks to the anonymous reviewers and editors for their helpful and supportive comments.

\section{References}

Antaki C and Widdicombe S. (1998) Identities in Talk. London: Sage Publications.

Arnett JJ. (1994) Are College Students Adults? Their Conceptions of the Transition to Adulthood. Journal of Adult Development 1: 213-224.

Arnett JJ. (2000) High Hopes in a Grim World: Emerging Adults' Views of their Futures and 'Generation X'. Youth and Society 31: 267-286.

Arnett JJ. (2004) Emerging Adulthood: The Winding Road from the Late Teens through the Twenties, Oxford: Oxford University Press.

Arnett JJ. (2006) Emerging Adulthood in Europe: A Response to Bynner. Journal of Youth Studies 9: 111-123.

Arnett JJ. (2007) Suffering, Selfish, Slackers? Myths and Reality about Emerging Adults. Journal of Youth and Adolescence 36: 23-29.

Baker C. (1984) The 'Search For Adultness': Membership Work In Adolescent-Adult Talk. Human Studies 7: 301-323.

Baker C. (2000) Locating Culture in Action: Membership Categorisation in Texts and Talk. In: Lee A and Poynton C (eds) Culture and Text: Discourse and Methodology in Social Research and Cultural Studies. St Leonards, NSW: Allen \& Unwin, 99-113. 
Baker C. (2002) Ethnomethodological Analysis of Interviews. In: Gubrium JF and Holstein JA (eds) The Handbook of Interview Research: Context and Method. London: Sage Publications, 777-795.

Ball SJ, Maguire M and Macrae S. (2000) Choice, Pathways and Transitions Post-16: New Youth, New Economies in the Global City, London: Routledge.

Beckett F. (2010) What Did the Baby Boomers Ever Do for Us?, London: Biteback.

Ben-Amos IK. (1995) Adolescence as a Cultural Invention: Philippe Aries and the Sociology of Youth. History of the Human Sciences 8: 69-89.

Billig M. (1999) Whose Terms? Whose Ordinariness? Rhetoric and Ideology in Conversation Analysis. Discourse and Society 10: 543-558.

Blatterer H. (2005) Reconceptualising an Uncontested Category: Contemporary Adulthood and Social Recognition. Paper presented at Frontiers of Sociology, The 37th World Congress of the International Institute of Sociology. Stockholm, Sweden. 5-9th July.

Blatterer H. (2007a) Coming of Age in Times of Uncertainty, Oxford: Berghahn Books.

Blatterer H. (2007b) Contemporary Adulthood: Reconceptualizing an Uncontested Category. Current Sociology 55: 771-792.

Blatterer H. (2010a) The Changing Semantics of Youth and Adulthood. Cultural Sociology 4: 63-79.

Blatterer H. (2010b) Generations, Modernity and the Problem of Contemporary Adulthood. In: Burnett J (ed) Contemporary Adulthood: Calendars, Cartographies and Constructions. Basingstoke: Palgrave MacMillan, 10-23.

Brooks R. (2003) Young People's Higher Education Choices: The Role of Family and Friends. British Journal of Sociology of Education 24: 283-297.

Buhl H. (2009) My Mother: My Best Friend? Adults’ Relationships with Significant Others Across the Lifespan. Journal of Adult Development 16: 239-249.

Burnett J. (2010) Contemporary Adulthood: Calendars, Cartographies and Constructions. Basingstoke: Palgrave MacMillan.

Côte JE. (2000) Arrested Adulthood: The Changing Nature of Maturity and Identity, New York: New York University Press.

Côte JE. (2002) The Role of Identity Capital in the Transition to Adulthood: The Individualization Thesis Examined. Journal of Youth Studies 5: 117-134.

Côte JE and Bynner J. (2008) Changes in the Transition to Adulthood in the UK and Canada: The Role of Structure and Agency in Emerging Adulthood. Journal of Youth Studies 11: 251-268.

EGRIS. (2001) Misleading Trajectories: Transition Dilemmas of Young Adults in Europe. Journal of Youth Studies 4: 101-118.

Furlong A and Cartmel F. (2007) Young People and Social Change: New Perspectives, Buckingham: Open University Press.

Garfinkel H. (2005) Seeing Sociologically: The Routine Grounds of Social Action, Boulder: Paradigm Publishers.

Goffman E. (1971) The Presentation of Self in Everyday Life, Harmondsworth: Penguin.

Have PT. (1999) Doing Conversation Analysis: A Practical Guide, London: Sage Publications.

Heath S. (2007) Widening the Gap: Pre-University Gap Years and the 'Economy of Experience'. British Journal of Sociology of Education 28: 89-103.

Henderson S, Holland J, McGrellis S, et al. (2007) Inventing Adulthoods: A Biographical Approach to Youth Transitions, London: Sage Publications. 
Hockey J and James A. (1993) Growing up and Growing Old: Ageing and Dependency in the Life Course, London: Sage Publications.

Holdsworth C and Morgan D. (2005) Transitions in Context: Leaving Home, Independence and Adulthood, Maidenhead, Berks.: Open University Press.

Holmstrom LL, Karp DA and Gray PS. (2002) Why Laundry, Not Hegel? Social Class, Transition to College, and Pathways to Adulthood. Symbolic Interaction 25: 437-462.

Holstein JA and Gubrium JF. (1995) The Active Interview, London: Sage Publications.

Honneth A. (1996) The Struggle for Recognition: The Moral Grammar of Social Conflicts, Cambridge: MIT Press.

Horowitz AD and Bromnick RD. (2007) "Contestable Adulthood": Variability and Disparity in Markers for Negotiating the Transition to Adulthood. Youth and Society 39: 209-231.

Howker E and Malik S. (2010) Jilted Generation: How Britain Has Bankrupted its Youth, London: Icon Books.

Hutchby I and Moran-Ellis J. (1998) Situating Children's Social Competence. In: Hutchby I and Moran-Ellis J (eds) Children and Social Competence: Arenas of Action. London: Falmer Press. p7-26.

Jayyusi L. (1984) Categorization and the Moral Order, Boston: Routledge and Kegan Paul.

Jenks C. (1996) Childhood, London: Routledge.

Jones A. (2004) Review of Gap Year Provision. London: Department for Education and Skills.

Jones G. (1995) Leaving Home, Buckingham: Open University Press.

Jones G. (2002) The Youth Divide: Diverging Paths to Adulthood. York: Joseph Rountree Foundation.

Jones G and Wallace C. (1990) Beyond Individualization: What Sort of Social Change? In: Chisholm L, Buchner P, Kruger H-H, et al. (eds) Childhood, Youth and Social Change: A Comparative Perspective. London: RoutledgeFalmer, 134-154.

King A. (2009) 'Mind the Gap': Reassessing Transitions to Adulthood Using Young People's Accounts of Undertaking Short-Term Employment. In: Brooks R (ed) Transitions from Education to Work: New Perspectives from Europe and Beyond. Basingstoke: Palgrave MacMillan.

King A. (2010) Membership Matters: Applying Membership Categorisation Analysis (MCA) to Qualitative Data Using Computer Assisted Qualitative Data Analysis (CAQDAS) Software. International Journal of Social Research Methodology 13: 1-16.

King A. (2011) Minding the gap? Young people's accounts of taking a Gap Year as a form of identity work in higher education. Journal of Youth Studies 14: 341357.

Laz C. (1998) Act Your Age. Sociological Forum 13: 85-113.

Lepper G. (2000) Categories in Text and Talk: A Practical Introduction to Categorization Analysis, London: Sage Publications.

MacDonald R and Marsh J. (2005) Disconnected Youth? Growing Up in Britain's Poor Neighbourhoods, Houndmills, Basingstoke: Palgrave MacMillan.

Maguire M, Ball SJ and Macrae S. (2001) Post-Adolescence, Dependence and the Refusal of Adulthood. Discourse: Studies in the Cultural Politics of Education 22: 197-211. 
Monteith M. (2003) Making Progress? The Transition to Adulthood for Disabled Young People in Northern Ireland. In: Kellet M, Lewis V, Robinson C, et al. (eds) The Reality of Research with Children. London: Sage Publications. p162-185, 162-185.

Nikander P. (2002) Age in Action: Membership Work and Stage of Life Categories in Talk, Helsinki: Finnish Academy of Science and Letters.

Pais JM. (2003) The Multiple Faces of the Future in the Labyrinth of Life. Journal of Youth Studies 6: 115-126.

Phillipson C. (1982) Capitalism and the Construction of Old Age, London: MacMillan Press.

Pilcher J, Williams J and Pole C. (2003) Rethinking Adulthood: Families, Transitions and Social Change. Sociological Research Online 8.

Plug W and du Bois-Raymond M. (2006) Transition Patterns Between Structure and Agency. In: Walther A, du Bois-Raymond $\mathrm{M}$ and Biggart $\mathrm{A}$ (eds) Participation in Transition. Frankfurt am Main: Peter Lang. p107-126, 107126.

Potter J. (1996) Representing Reality: Discourse, Rhetoric and Social Construction, London: Sage Publications.

Proulx CM and Helms HM. (2008) Mothers' and Fathers' Perceptions of Change and Continuity in their Relationships with Young Adult Sons and Daughters. Journal of Family Issues 29: 264-261.

Qvortrup J. (1994) Childhood Matters: An Introduction. In: Qvortrup J, Bardy M, Sgritta G, et al. (eds) Childhood Matters: Social Theory, Practice and Politics. Aldershot: Avebury. p1-24, 1-24.

Rawnsley A. (2006) The Age War Is Here - And the Young Are Losing It to the Old. The Observer. London.

Sacks H. (1995) Lectures on Conversation: Volumes 1\&2, Oxford: Blackwell.

Scanlon L, Rowling L and Weber Z. (2007) 'You Don't Have Like an Identity...You Are Just Lost in a Crowd': Forming a Student Identity in the First-year Transition to University. Journal of Youth Studies 10: 223-241.

Schegloff EA. (1997) Whose Text? Whose Context? Discourse and Society 8: 165187.

Shanahan MJ. (2000) Pathways to Adulthood in Changing Societies: Variability and Mechanisms in Life Course Perspective. Annual Review of Sociology 26: 667692.

Silverman D. (1998) Harvey Sacks: Social Science and Conversation Analysis, Oxford: Polity Press.

Simpson K. (2005) Dropping Out or Signing Up? The Professionalisation of Youth Travel. Antipode 37: 447-469.

Smith D. (1978) K is Mentally Ill: The Anatomy of a Factual Account. Sociology 12: 23-53.

Thomson R, Bell R, Holland J, et al. (2002) Critical Moments: Choice, Chance and Opportunity in Young People's Narratives of Transition. Sociology 36: 335354.

Wallace C. (1987) For Richer, For Poorer: Growing Up In and Out of Work, London: Tavistock Publications.

Weatherall A. (2000) Gender Relevance in Talk-in-Interaction and Discourse. Discourse and Society 11: 286-288.

Wells T, Sandefur GD and Hogan DP. (2003) What Happens after the High School Years among Young Persons with Disabilities? Social Forces 82: 803-832. 
Widdecombe S and Wooffitt R. (1995) The Language of Youth Subcultures: Social Identity in Action, New York: Harvester Wheatsheaf.

Willetts D. (2010) The Pinch: How the Baby Boomers Took their Children's Future and How They Can Give It Back, London: Atlantic Books.

Wyn J. (2004) Becoming Adult in the 2000s: New Transitions and New Careers. Family Matters: 6-12.

Andrew King is a senior lecturer in Sociology, School of Social Science, Kingston University, London. His research interests concern the intersection of age and identity, particularly as these relate to young people and older LGBT adults. He is also interested in qualitative methodologies, particularly conversation analysis.

\section{Corresponding author:}

Andrew King, School of Social Science, Kingston University, Penrhyn Road, Kingston upon Thames KT1 2EE

Email: a.king@kingston.ac.uk

\footnotetext{
${ }^{\mathrm{i}}$ It is impossible within the confines of this paper to discuss the validity, or otherwise, of such an approach but for a good overview of the debate see Billig M. (1999) Whose Terms? Whose Ordinariness? Rhetoric and Ideology in Conversation Analysis. Discourse and Society 10: 543-558, Schegloff EA. (1997) Whose Text? Whose Context? Discourse and Society 8: 165-187, Weatherall A. (2000) Gender Relevance in Talk-in-Interaction and Discourse. Discourse and Society 11: 286-288.
} 